\title{
SHORT RUN CAUSAL RELATIONSHIP BETWEEN FOREIGN DIRECT INVESTMENT (FDI) AND INFRASTRUCTURE DEVELOPMENT
}

\begin{abstract}
Purpose: Foreign Direct Investment (FDI) flows for infrastructure development have grown in volume to become more widely dispersed among home (outward investor) and host (recipient) countries. This paper explores the short run causal relationship between FDI and infrastructure development in the developing country of Ghana.

Approach: A two-stage least squares (2SLS) estimation method was adopted where FDI was endogenized and all variables were in constant prices. Stationarity tests were performed on the annualized log difference of variables using Augmented Dickey-Fuller Test (ADF).

Findings: Results reveal a positive and significant relationship between FDI and infrastructure but a negative and significant relationship between FDI and GDP and FDI and openness. GDP growth also has a long run negative relationship with FDI inflows.

Originality: The paper's contribution to knowledge is two-fold. First, it examines the short run effect of FDI upon the Ghanaian economy and how market shocks to FDI and infrastructure development can be ameliorated. Second, it illustrates that Government policy makers should prioritize development that requires FDI and ensure that the local market is not excessively open to foreign exploitation. Future work is required to further investigate international capital flow and its impact upon other developing nations.
\end{abstract}

\section{KEYWORDS}

Foreign Direct Investment (FDI), Gross Domestic Product, Infrastructure; Sub-Saharan Africa, Ghana.

\section{INTRODUCTION}

Since the early 1980s, global Foreign Direct Investment (FDI) flow (estimated to involve over 54,000 transnational corporations) has grown faster than world trade and world output (Amiti and Wei, 2006). Agiomirgianakis et al. (2003) state that FDI can be defined as capital flows resulting from the behaviour of multinational companies (MNCs) - thus, the factors to affect the behaviour of MNCs may also affect the magnitude and the direction of FDI. FDI provides an 
important source of private external finance for developing countries and is primarily motivated by investors' long-term desire to make profits in production activities that they directly control (Choe, 2003). While FDI represents investment in production facilities, its significance for developing countries is much greater (De Mello, 1999). FDI contributes to investible resources and capital formation but also facilitates transference of production technology, skills, innovative capacity, organizational and managerial practices and access to international marketing networks. Beneficiaries include enterprises operating within transnational systems but these opportunities can also transfer to domestic firms within a host country provided the economic environment is conducive (Blonigen et al., 2005). The greater the supply and distribution links between foreign affiliates and domestic firms, the stronger the domestic firms' capabilities to enhance competitiveness (Sethi et al., 2003). Balasubramanyam et al., (1996) analyzed how FDI affects economic growth in developing economies. Using cross-section data and OLS regressions they (ibid) found that FDI has a positive effect upon economic growth in host countries using an export promoting strategy but not in countries using an import substitution strategy. Olofsdotter (1998) conducted similar analysis using cross sectional data and found that an increase in FDI stock is positively related to economic growth. The research (ibid) found that the effect is stronger for host countries with a higher level of institutional capability - as measured by the degree of property rights protection and bureaucratic efficiency in the host country. A more contemporary study by Olatunji and Shahid (2015), found a short-run dynamic relationship between FDI and economic growth, and suggested that the long-run relationship can be achieved through infrastructure development and political stability. However, extant literature also reveals that the main deterrents to attracting FDI in developing countries include: governance failure, problems of policy credibility, macroeconomic policy failures and poor liberalization policies (Anyanwu, 2011; Alfaro et al., 2004; Asiedu, 2003).

Given the aforementioned context, this paper seeks to explore the short run causal relationship between FDI and infrastructure development in the developing country of Ghana. Unlike previous studies on FDI that used cross-sectional data to examine the relationship between FDI, infrastructure and growth, this paper uses country specific data and further explores the effect of market shocks to FDI and infrastructure development. A greater understanding in this area of 
infrastructure development could help policy-makers design effective policies to attract FDI inflow into sectors where investment is most needed.

\section{FOREIGN DIRECT INVESTMENT (FDI)}

Growth in FDI accelerated in the 1990s, rising to $\$ 331$ billion in 1995 and $\$ 1.3$ trillion in 2000 (UNCTAD, 2002). Consequently, developing countries experienced a sharp increase in the average ratio of FDI to total investment during the 1990s. A principal feature of FDI growth has been its meteoric rise in the services sector, which is now the dominant sector in global FDI. For developing countries, FDI in the services sector increased at an annual rate of $28 \%$ over the period 1988 to 1999 but by 1999 it accounted for 37\% of total foreign investment inflows. A significant part of this increase has been the growth in private capital flows for infrastructure in response to the general trend towards privatization of infrastructure in developing countries (WIR, 2012). Private investment in developing countries has risen dramatically since 1990 and the annual investment commitments reached a peak of $\$ 128$ billion in 1997. According to the World Bank's Private Participation in Infrastructure (PPI) database, 26 countries awarded 72 infrastructure projects with private participation in 1984-89 - attracting almost $\$ 19$ billion in investment commitments. In the 1990s, 132 low- and middle-income countries pursued PPI and transferred the operational responsibility for almost 2,500 infrastructure projects, attracting investment commitments of more than $\$ 750$ billion (WIR, 2012).

FDI inflows have been inconsistent and in 2012 they decreased in all three major economic groups - developed, developing and transition economies albeit at different rates (Asiedu, 2002; Seabra and Flach, 2005). In developed countries, FDI flows fell by 32 per cent to $\$ 561$ billion while many European Union (EU) countries and the United States (US) experienced significant drops in their FDI inflows (WIR, 2012). Interestingly, FDI flows to developing economies

remained relatively resilient, declining by only 4 per cent (World Bank, 2012). FDI inflows to small economies rose further in 2012 from $\$ 56$ billion in 2011 to $\$ 60$ billion, owing to the strong growth of FDI to least developed countries (LDCs) and small island developing States (SIDS). Outward FDI from developed economies declined by $\$ 274$ billion in 2012, accounting for almost all of the fall in global outward FDI. In contrast, FDI flows from developing economies rose by 1 per cent in 2012, amounting to $\$ 426$ billion. FDI outflows from Africa almost tripled while flows 
from Asia, Latin America and the Caribbean remained constant at the 2011 level (World Bank, 2012).

Africa is one of the few regions to enjoy year-on year growth in FDI inflows since 2010. Investment in exploration and exploitation of natural resources, and high investment from China both contributed to the current level of inward flows (WIR, 2012). More generally, the continent's good economic performance (i.e., GDP grew by 5 per cent in 2012) underpinned the rise in investment. In Mauritania, FDI inflows doubled to $\$ 1.2$ billion, partly attributable to an expansion in mining operations (copper and gold) by Canada-based First Quantum Minerals and Kinross. Central Africa attracted \$10 billion of FDI in 2012, a surge of 23 per cent on the previous year. Recent natural resource discoveries also contributed to the increase in FDI inflows to East Africa, from $\$ 4.6$ billion in 2011 to $\$ 6.3$ billion in 2012 following the discovery of gas reserves in the United Republic of Tanzania and oil fields in Uganda (WIR, 2012). Outward FDI flows from Africa nearly tripled in 2012, from $\$ 5$ billion in the previous year to an estimated $\$ 14$ billion. In contrast, FDI flows to West Africa declined by 5 per cent, to $\$ 16.8$ billion, mainly because of decreasing flows to Nigeria caused by a toxic combination of political insecurity and the weak global economy (Word Bank, 2012). Slowing FDI inflows to the Congo were offset by an increase to the Democratic Republic of the Congo, where inward FDI flows jumped from $\$ 1.7$ billion to $\$ 3.3$ billion. Some of the flows went towards the expansion of the copper-cobalt Tenke Fungurume mine.

\section{FDI in Ghana}

Foreign capital (both direct and indirect investment) is constantly in demand (Agiomirgianakis et al. 2003). Loans from international commercial banks were initially favoured but during the 1980s, commercial bank lending dried up because of debt crises and forced many countries to reform their investment policies to attract more stable forms of foreign capital - including FDI (WIR, 2012). Developing world governments proactively seek economic policies reform (such as domestic labour market conditions, corporate taxes, tariff barriers, subsides and privatization) to improve FDI activity in their countries (ibid). However, only a few sub-Saharan African countries have been successful in attracting significant FDI inflows. The historical trend of FDI inflows into Ghana can be aggregated into three main phases (Tsikata et al., 2000). During 1983- 
88 sluggish inflows were recorded, averaging about $\$ 4$ million per annum with the highest and lowest inflows being \$6 million in 1985 and \$2 million in 1984. During 1989-1992 moderate inflows were recorded, averaging about $\$ 18$ million per annum with the highest and lowest being \$22 million in 1992 and \$14.8 million in 1990 respectively. During 1993-1996 oscillatory inflows occurred which peaked in 1994 at $\$ 233$ million but fell by > 50\% the following year to $\$ 107$ million. The latest value of FDI in Ghana during 2013 was $(\$ 3,226,300,000.00$ (US\$). Tsikata et al., (ibid) suggest that a three-way nexus of economic growth, investment and political stability is an important feature of FDI inflows- particularly since Ghana's coup d'état of 1972. During this period, a growth rate of $2.3 \%$ was recorded, accompanied by $>60 \%$ drop in FDI (from $\$ 30.6$ million in 1971 to $\$ 11.5$ million in 1972). Similar trends were experienced after the 1979 and 1981 coup d'état when growth fell to as low as 3.2\%. The state of the economy worsened further with a negative growth rates of $-3.5 \%$ in 1981 to $-6.9 \%$ in 1982 ; however inflow of FDI remained constant at $\$ 16.3$ million (ibid).

\section{ANTECEDENTS OF FDI}

Various theories developed to explain the determinants of FDI are incapable of providing a generic theory that explains all variants (i.e., outward and inward FDI at the firm, industry and country level) (Itaki, 1991). However, Dunning (1993) describes three main types of motivebased FDI from the investment firms' perspective, namely: i) market-seeking (or horizontal) FDI aims to serve local and regional markets replication of production facilities in the host country. Tariff-jumping or export-substituting FDI is a variant of this type of FDI; ii) resourceseeking (or vertical) which involves firms investing abroad to obtain scarce resources such as natural resources, raw materials or low-cost labour (World Bank, 2012). In contrast to marketseeking FDI, resource-seeking FDI involves relocating parts of the production chain to the host country; iii) efficiency-seeking occurs when a firm can gain from the common governance of geographically dispersed activities in the presence of economies of scale and scope (WIR, 2012). In 1998, the World Investment Report, UNCTAD (1998) analysed the determinants of FDI and classified these into three thematic groups, namely: i) political factors; ii) business facilitation; and iii) economic factors. However, the absence of a generally accepted theoretical framework has led researchers to rely on empirical evidence (such as market size and openness) for explaining the emergence of FDI. 
Market Size - Artige and Nicolini (2005) and Pärletun (2008) state that market size as measured by GDP (or GDP per capita) is the most robust market-seeking FDI determinant in econometric studies yet, GDP is irrelevant for resource-seeking FDI (Artige and Nicolini, 2005). Jordaan (2004) proffers that FDI flows to countries with larger/expanding markets and greater purchasing power because firms can receive a higher return on investment. A larger market enables the efficient utilization of resources and exploitation of economies of scale, hence a positive correlation exists between market growth and FDI (Charkrabarti, 2001). The Overseas Development Institute (ODI), 1997, state that this correlation serves as a proxy for the size of GDP and some of its characteristics (such as average income levels). Jaspersen et al., (2000) use the inverse of income per capita as a proxy for the return on capital and conclude that real GDP per capita is inversely related to FDI/GDP. Schneider and Frey (1985), Tsai (1994) and Asiedu (2002) suggest that a higher GDP per capita implies better prospects for FDI in the host country.

Openness - Openness is a ratio that measures the relationship between exports/imports to GDP (Charkrabarti, 2001). A country's degree of openness to international trade will impact on FDI dependent upon the type of investment (Jordaan, 2004). When investments are market-seeking, trade restrictions (and therefore reduced openness) can have a positive impact on FDI as a result of 'tariff jumping.' Traffic jumping occurs when foreign firms seek to serve local markets by establishing subsidiaries in the host country (ibid). In contrast, MNCs engaged in export-oriented investments may prefer to invest in a more open economy since increased imperfections that accompany trade protection generally imply higher transaction costs associated with exporting (Kravis and Lipsey, 1982; Wheeler and Mody, 1992).

Labour Costs and Productivity - Charkrabarti (2001) claims that labour costs (or wages) are the most contentious of all the potential determinants of FDI. Affordable labour is essential to attracting multinationals however, how wage levels affect FDI remains largely debatable. Goldsbrough (1979), Saunders (1982) and Schneider and Frey (1985) demonstrate that higher wages discourage FDI. Conversely, Tsai (1994) suggests that high wages are not always a barrier to FDI. For example, the ODI (1997) suggest that when wage rates vary little from country to country, the skills of the labour force exert an impact upon decisions about FDI location. 
Political Risk - According to ODI (1997), politically instable host countries laden with rich natural resources are attractive to FDI because high returns compensate for risks posed. For example, large mining companies have overcome political risks by investing in their own infrastructure maintenance and security forces (Jaspersen et al., 2000). These companies are limited neither by small local markets nor by exchange-rate risks because they sell almost exclusively on the international market at hard currency prices. Specific proxy variables (e.g. number of strikes and riots and work days lost) have proved significant in some studies but these quantitative estimates can only capture some aspects of the qualitative nature of political risk. Indeed, the empirical relationship between political instability and FDI flows remains unclear within extant literature. While Jaspersen (ibid) and Hausmann and Fernandez-Arias (2000) find no relationship between FDI flows and political risk, Schneider and Frey (1985) find an inverse relationship between the two variables.

Infrastructure - Poor infrastructure presents both an obstacle and opportunity for FDI (ODI, 1997). For many low-income countries, inadequate infrastructure represents a major constraint but foreign investment can be attracted when host governments permit substantial foreign participation in national infrastructure development (ibid). Jordaan (2004) claims that good quality and well-developed infrastructure increases the productivity potential of investments and therefore stimulates FDI flows into the country.

Growth - The relationship between growth and FDI remains largely inconclusive. Lunn (1980) states that a rapidly growing economy provides relatively better opportunities for making profits than the ones growing slowly or not growing at all. Later research published by Lin (1983), Schneider and Frey (1985) and Gastanaga et al. (1998) confirm the presence of a significantly positive effect of growth upon FDI. However, time series analysis conducted by Tsai (1994) produced conflicting evidence of a positive correlation over the survey period 1983 to 1986 but a weak correlation between 1975 to 1978 . This weak correlation between these growth and FDI was supported by Nigh (1985) and Ancharaz (2003). 
Tax - Tax is also a contentious issue. Hartman (1994), Grubert and Mutti (1991), Hines and Rice (1994), Loree and Guisinger (1995) and Kemsley (1998) suggest that host country corporate income taxes have a significant negative effect on attracting FDI flows. However, Wheeler and Mody (1992), Jackson and Markowski (1995) and Porcano and Price (1996) conclude that taxes do not have a significant effect on FDI.

The direction of the effects of above mentioned determinants may positively or negatively affect FDI. Moosa (2005) states that due to the absence of a consensus on a theoretical framework to guide empirical work on FDI, there is no widely accepted set of explanatory variables that can be regarded as the 'true' determinants of FDI.

\section{THEORIES ON FDI}

Early works of FDI theory can be attributed to MacDougall (1958) who established his model based on the assumptions of a perfectly competitive market. This theory (ibid) was further elaborated upon by Kemp (1964). Assuming a two-country model and prices of capital being equal to its marginal productivity, MacDougall (1958) and Kemp (1964) both stated that when there was free movement of capital from an investing country to a host country, the marginal productivity of capital tended to be equalized between the two countries. They found that after investment, the output of the investing country fell without any decrease in the national income of the country. This is because in the long term, the investing country receives higher income from its investment abroad. Since this early work a number of alternative and/or supplementary theories have been developed.

Industrial organization approach: Hymer (1976) established the systematic industrial organisation approach towards the study of FDI. This theory sought to explain international production in an imperfect market framework and was supported by Lemfalussy (1961), Kindleberger (1969), Knickerbocker (1973) and Dunning (1974). The industrial organisation theory asserts that firms operating abroad have to compete with domestic firms that are in an advantageous position in terms of culture, language, legal system and consumers' preference. Furthermore, foreign firms are also exposed to foreign exchange risk. These disadvantages must be offset by some form of market power in order to make international investment profitable. 
FDI based on monopolistic power: Kindleberger (1969) extended Hymer's work (1976) and argued that advantages enjoyed by MNCs could be useful only in the case of market imperfection such as superior technology, managerial expertise and patents. These advantages encourage firms to invest in a foreign market in order to fully exploit them vis-a-vis share them with potential competitors. Greater opportunities to earn monopoly profits encourage more firms to invest directly. Although, Kindleberger (1969) described various forms of advantages enjoyed by a foreign firm (over the host country firm), the specific advantage upon which a firm should focus was not elucidated upon. Further, a firm can only exploit its monopolistic advantages abroad if the host country's policies allow it to do so - often and in the name of national interest, a host Government would be unwilling to permit free entry of foreign firms into the country.

Internalization theory of FDI: Buckley and Casson (1976) conceptualized FDI by emphasizing intermediate inputs and technology and shifting the focus of international investment theory away from country-specific towards industry-level and firm-level determinants of FDI (Henisz, 2003). Buckley and Casson (ibid) analyzed MNCs within a broad-based framework developed by Coase (1937). Buckley and Casson (1976) articulated their theory based upon three postulates that: i) firms maximize profits in a market that is imperfect; ii) when markets for intermediate products are imperfect, there is an incentive to bypass them by creating internal markets; and iii) internalization of markets across the world leads to MNCs.

Oligopolistic theory explaining FDI: Knickerbocker's (1973) theory was also formulated based on market imperfections. The three important motives for choosing a particular country as a new business location are: i) firms seek increased access to the host country's market; ii) firms want to take advantage of the relatively abundant natural resources available in that country; and iii) firms might invest in a country to match a rival's move and avoid the risk of being underpriced (Head et al., 2002; Altomonte and Pennings, 2003).

Eclectic Paradigm to FDI: Dunning (1977 and 1979) amalgamated the major imperfect market (i.e. oligopolistic and internalization theories) and added a third 'location theory' dimension explain why a firm opens a foreign subsidiary. Location theory seeks to determine who produces 
what goods or services in which locations and why? Enumerated factors considered include host country policies, economic fundamentals, firm strategy and agglomeration economies.

Endogenous Growth Theory: suggests that economic growth is generated by factors such as economies of scale, increasing returns on investment or induced technological changes which are within the production process (Romer, 1990). Grossman and Helpman (1991) developed growth models within the endogenous growth theory to explain the relationship between FDI and growth. These models assume that technological progress (including knowledge transfer and innovation) is the principal driving force of economic growth. Therefore, these models place emphasis on human capital accumulation and externalities on growth. Developing countries are generally unable to innovate and generate new technologies, therefore they adopt technology(ies) produced from advanced countries through FDI. New growth theories indicate bidirectional causality between FDI and growth (Borensztein et al., 1998). This is because FDI is expected to improve economic growth by encouraging the incorporation of new foreign technologies in the production function of the beneficiary country. FDI also enhances growth by adding to the host country's existing knowledge base through human resource training and development and increases competition in the host country by overcoming entry barriers and reducing the market power of existing firms (Dunning 1993; Borensztein et al., 1998 and De Mello, 1999).

\section{Infrastructure and Foreign Direct Investment (FDI)}

FDI inflow is a key factor of economic development especially for developing countries since it provides: a substantial financial resource; an opportunity to transfer technological, organizational and managerial practices and skills; and access to international markets (c.f. Shatz and Venables, 2000; Alfaro et al., 2004). MNEs have played an essential role in shaping the patterns of economic development through their FDI decisions (c.f. McCann and Mudambi, 2004). Since the 1997 global economic crisis, many developing countries have primarily relied upon FDI inflow for economic/ infrastructural development on a sustainable basis. Infrastructure development is widely considered as a crucial factor influencing the desirability of investment location, particularly for developing economies, such as Ghana. However, few studies have examined the effect of FDI inflows on infrastructure development. For instance, Frimpong and Oteng-Abayie, (2007) studied the causal link between FDI and GDP growth for Ghana for the pre- and post- 
Structural Adjustment Programme (SAP) periods. In other developing economies Lipsey and Sjoholm (2011) studied the relationship between growth and FDI in East Asian countries. Moreover, Takii (2005) discussed the role of FDI by examining productivity spillovers from foreign multinational plants; and Takii (2011) examined the effect of FDI on economic growth in relation to the origin of investors in Indonesian manufacturing. Despite the growing importance of FDI inflows in developing economies, empirical evidence is limited on the determinants of location choice of FDI inflows at their regional level.

\section{RESEARCH METHOD}

The study uses annual time series data covering the period 1984-2013 (based on the availability of data). Data sets were obtained from: the World Bank (African Development Indicators Database); the Ministry of Finance and Economic Planning (Fiscal Data); and the Institute of Statistical, Social and Economic Research (ISSER) and Centre for Policy Analysis (CEPA) publications. All variables are in constant prices. The estimation procedures are undertaken with the aid of Stata 12 and Eviews 8 software packages. A two-stage least squares (2SLS) estimation method was adopted where FDI was endogenized; this approach enables any simultaneity issues to be overcome (c.f. Mansouri, 2005; Omoniyi and Omobitan, 2011). The model considers the impact of Infrastructure on FDI inflows in Ghana and is formulated as:

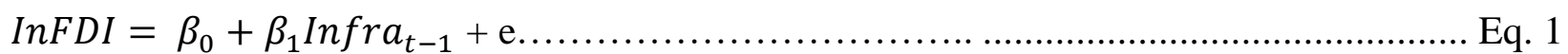

Where Infra is the log of infrastructure, FDI represents the log of FDI inflows and $\boldsymbol{e}$ represents the error term

\section{Unit Root Test}

Macroeconomic variables usually have a time dependent moment (non-stationary) which poses problems in the estimation results as the standard assumptions for asymptotic analysis would not be valid. Consequently, estimating with ordinary least squares in the presence of non-stationary variables will lead to spurious results. Testing whether a given set of macroeconomic variables is stationary or not in time series analysis is critical to establishing model validity. Econometricians suggest the use of standard time-series unit root tests such as the Augmented Dicky Fuller test, 
Phillips-Perron and Dickey-Fuller test with Generalized Least Squares Detrending (DF-GLS) to check the stationarity of variables (Baum, 2000). The study uses the DF-GLS test as it is far more robust than .alternative/ complementary tests available. The DF-GLS is computed as follows:

$\Delta X_{t}^{\prime}=\beta+\rho t+\delta X_{t-1}^{\prime}+\sum_{v=1}^{p} \gamma_{v} \Delta X_{t-1}^{\prime}+$

where $X_{t}^{\prime}$ is the detrended series; $t$ is the time trend $\beta, \delta$ and $\Delta$ are the constant or drift parameter (an arbitrary parameter and the first-difference operator respectively); $\gamma_{v}$ represents the coefficients of the lagged difference terms and is a error term.. The null and the alternate hypothesis for the presence of unit root in the variable $X_{t}$ for the DF-GLS tests are:

$$
\begin{aligned}
& H_{0}: \delta=0 \text { (stationary) } \\
& H_{1}: \delta<0 \text { (non-stationary) }
\end{aligned}
$$

Rejecting the null hypothesis leads to the conclusion that the variable is not stationary and autocorrelation exists which will produce inaccurate estimates and incorrect inference generation. The presence of arch effects requires the use of lagged variables to achieve stationarity. To determine the optimal lag length (k), the Akaike Information Criterion (AIC) and Schwarz-Bayesian Criterion (SBC) are widely used.

\section{MODEL ESTIMATION AND ANALYSIS}

The economic variables included in the model are: growth rate per capita GDP (gdppc) and population size (pop) which are proxies for market size; inflation (inf), measured as yearly percentage change in consumer prices and GDP growth (grw) - as proxies for economic stability; net exports (nx) - proxy for openness; and M2 as a percentage of GDP (Mg), - proxy for financial development and exchange rate volatility - measured as the variance of the US/GHS exchange rate around it mean - proxy for risk. Descriptive analysis of the observed variables below illustrates that annual change in the macroeconomic over the sample period (1984-2013) has been is very high. For example, net inflows of FDI over the sample period is averaging at $18.4 \%$ annually with a standard deviation of $2.302 \%$ and growth of electricity 
consumption increases by 5.7 percentage points annually (refer to Table 1). A similar trend is apparent for the real effective exchange rate over the sample period. Growth in GDP has been changing annually at approximately $1.522 \%$ which is circa half of the annual change in inflation rate and trade openness.

\section{<Insert Table 1 About Here>}

Unit Root Test Results: Stationarity tests were performed on the annualized log difference of variables using ADF. Tests were performed on both constant and constant with trend at 1\%, 5\% and $10 \%$ levels of significance. Table 2 illustrates that inflation rate, GDP growth and electricity consumption were stationary at levels, indicating that there is no unit root at first difference with constant. However, FDI and real effective exchange rate (REEXR) were both found to possess a unit root at first difference with constant but when detrended, results reveal that the two series are stationary.

\section{<Insert Table 2 About Here>}

Figure 1 provides a graphical illustration of all the variables including FDI and real exchange rate after detrending. All variables illustrate little evidence of trend or drift at first difference. Having determined that the null hypothesis of non-stationarity at levels cannot be accepted, the cointegration of the variables is explored.

\section{<Insert Figure 1 About Here>}

\section{Test of Cointegration}

Since all the variables are first difference stationary, it was prudent to check for cointegration among the variables. The Johansen's cointegration test was consequently performed using a maximum lag of 4. Results indicate (Table 3 ) that there are at least 3 cointegrating ranks among the variables. The associated trace statistic of 42.5303 reveals that the null hypothesis of "no cointegration among the variables' must be strongly rejected.

\section{<Insert Table 3 About Here>}


Results in Table 4 illustrate that all models normalized on ln_FDI, ln_Electricity, ln_GDP and ln_REEXR were statistically significant, thus the null hypothesis of 'no long run relationship' is rejected.

\section{<Insert Table 4 About Here>}

Primary attention is given to $\operatorname{lnFDI}$ and $\operatorname{lnElectricity}$ as the operational models. Since a long-run cointegration relationship is established using the two models, it can be implied that FDI net inflows has a long run relationship with annualized electricity consumption (as proxy measure for infrastructure).

\section{Determinants of Foreign Direct Inflows}

Given the observance of cointegration between variables, the determinants of FDI were estimated using cointegration regression estimators; specifically the Fully Modified OLS (FMOLS) and Conical Cointegration Regression (CCR) techniques. These methodologies provide a check for the robustness of results and have the ability to produce reliable estimates in small sample sizes. Results reproduced in Table 5 indicate that the estimates of the FMOLS and the CCR were very consistent and comparable indicating that the results were reliable. It is also revealed that electricity consumption and years have a positive and significant relationship on FDI. The coefficient of electricity consumption $\mathrm{B}=1.380, \mathrm{p}<1 \%$ in the FMOLS indicates that any $10 \%$ increase in electricity demand will generate a circa $13.8 \%$ increase in inflows of FDI. The same percentage reduction in electricity consumption causes a $13.7 \%$ improvement in inflows per the CCR estimation. Similarly, results on year indicate that FDI inflows have been growing at a yearly rate of $0.3 \%$ per annum.

\section{<Insert Table 5 About Here>}

In contrast, a negative and significant relationship was found to exist between FDI and GDP, and FDI and openness. This result is interesting because intuitively, one would suspect that openness of the economy to international trade would lead to an increase in FDI - this therefore confirms

the tariff-jumping hypothesis is evident in Ghana. The results show that a $10 \%$ openness in 
international trade through a reduction of import tariffs will lead to a 15.6 reduction in FDI according to the FMOLS model or a $15.5 \%$ reduction in FDI according to the CCR model. It is clear that GDP growth has a long run negative relationship with FDI inflows. Specifically a 10\% increase in GDP growth will induce at least a $40 \%$ reduction in FDI inflows based on the two models' estimates. This suggests that the 'market stealing' effect associated with increased FDI is apparent in Ghana; where MNCs push out domestic firms without FDI out of the market. The model's explanatory power using the adjusted $R$ squared is validated at around 90 percent for the fully modified OLS model and $87 \%$ for the CCR.

\section{Granger Causality Tests}

Based on evidence that a long run relationship exists between electricity consumption and FDI, the short run relationship between the two variables was then investigated. To determine the short run causal relationship between the two variables, the Granger Causality test was performed. Results indicated that there is strong evidence to support that growth in FDI net inflows helps to predict electricity consumption ( $p$-value is 0.003 seems like an odd p value); however, the growth in electricity demand does not cause the growth in FDI net inflows. Thus there is a uni-directional causal relationship between FDI net inflows and electricity consumption (refer to Table 6 below).

\section{<Insert Table 6 About Here>}

\section{Vector Autoregression (VAR) Analysis to Forecast FDI and Electricity Consumption}

To assess the behaviour of both FDI and electricity consumption (and forecast and conduct an impulse response analysis), VAR analysis was performed (see Table 7 below). The optimal lag length of 1 was selected minimum values of AIC, Hannan and Quinn information criterion (HQIC), final prediction error (FPE) and Schwarz's Bayesian information criterion (SBIC) criteria.

<Insert Table 7 About Here> 
The VAR analysis was conducted with $\ln \_$FDI and $\ln \_$Electricity as dependent variables; remaining variables were exogenous variables based upon a cointegration relationship. The validity of the VAR was checked for stability and autocorrelation and it was observed that none of the eigenvalues were close to unity - thus all shocks will die out with time. Table 8 reveals that all the eigenvalues were inside the unit circle and so VAR stability was confirmed.

\section{<Insert Table 8 About Here>}

Because the null hypothesis of no residual autocorrelation at all lag orders cannot be rejected at any significance level, there is no evidence to contradict the validity of the VAR models specified and forecasting can be performed. Figure 2 illustrates that electricity consumption is predicted to decline whereas net inflows of FDI are predicted to rise towards its steady path.

\section{<Insert Figure 2 About Here>}

\section{Effect of Structural Shocks on FDI and Infrastructure}

In order to identify the effect of shocks to FDI on electricity consumption (and vice versa), impulse response analysis was conducted. Because the Granger causality test generally supported a growth in FDI and electricity consumption, the study specifically chose this approach to examine the effect of FDI growth on electricity demand. Figure 3 illustrates that the diagonal panels show the effect of shocks to FDI and electricity consumption to its own growth path in the future. In both cases the shocks die out gradually confirming the stationarity of the variables.

\section{<Insert Figure 3 About Here>}

A one-standard deviation shock to electricity consumption in the top left of Figure 4 is slightly below $0.2 \%$ whereas a similar jump to the growth FDI net inflows is in excess of $0.4 \%$. The top right and the bottom left panels show the effect of a shock to one variable on the other. At the bottom left of Figure 4 it is observed that a one-standard deviation shock to FDI raises electricity consumption steadily for the next six months but by the year end unto the second year it attains a steady state. The top right panel, illustrates the effect of shocks to electricity consumption on 
FDI. A small dynamic effect is apparent that over a six months period which was to be expected. The variance decomposition results (refer to Figure 4) indicates the extent to which each shock contributes to unexplained movements (forecast errors) in each variable.

\section{<Insert Figure 4 About Here>}

For instance the left-column panels reveals that the electricity consumption shocks contribute $100 \%$ of the variance in the one-period-ahead forecast error for electricity consumption demand. However after the forecast horizon moves further into the next 6 months, the effect FDI inflows will be felt as the contributions converged to approximately $80 \%$ of variation in electricity demand. This is due to the electricity demand shocks and $20 \%$ due to the FDI shock. The rightcolumn panels indicate that $5 \%$ of the variation in FDI is attributable to electricity consumption growth shocks in the short run or long run.

\section{CONCLUSION}

Based upon the study context and proxies used for infrastructure and growth, it can be concluded that there is positive and significant relationship between FDI and infrastructure development. The coefficient of electricity consumption $\mathrm{B}=1.380, \mathrm{p}<1 \%$ in the FMOLS indicates that a $10 \%$ increase in electricity demand generates circa $13.8 \%$ increase in inflows of FDI. The same percentage point reduction in electricity consumption results in a $13.7 \%$ improvement in inflows per the CCR estimation. There was however a negative but significant relationship between FDI and GDP, and FDI and openness. This result supports the tariff-jumping hypothesis which states that foreign firms which seek to serve local markets may establish subsidiaries in the host country if it is difficult to import their products to that country. The study also concludes that $10 \%$ openness in the country's international trade either through reduction of import tariffs would lead to a $15.6 \%$ reduction in FDI according to the FMOLS model or a $15.5 \%$ reduction in FDI according to the CCR model. The results illustrate that GDP growth has a long run negative relationship with FDI inflows. Specifically a 10\% increase in GDP growth would induce at least a $40 \%$ reduction in FDI inflows based on the two models' estimates. Finally, a $0.2 \%$ shock to electricity consumption would result in a similar jump to the growth of FDI net inflows is in 
excess of $0.4 \%$. Moreover, a one-standard deviation shock to FDI raises electricity consumption steadily for the next six months but by the year end into the second year it attains a steady state.

Based upon these findings, it is recommended that managers of the country's economy should prioritize specific areas that require FDI. Incentives should be available to attract investments in such sectors. It is also important that areas prioritized are related and support local industries. Even though trade theorists encourage countries to engage in trade, care must be taken not to excessively open the country's market for exploitation without some trade restrictions to promote growth of local firms. To attract more FDI, governments need to commit additional resources towards infrastructure development particularly within the energy sector. This was evident in the study which indicates that any $10 \%$ increase in electricity infrastructure generates about $13.8 \%$ increase in inflows to foreign direct investments (FDI). This is because energy forms the backbone of every economy; therefore, infrastructure investments bring about long lasting solutions to the country's perennial energy challenges. 


\section{REFERENCES}

Agiomirgianakis, G., Asteriou, D. and Papathoma, K. (2003), The Determinants of Foreign

Direct Investment: A Panel Data Study for the OECD Countries. (Report No. 03/06). London,

UK: Department of Economics, City University London. Available via: http://openaccess.city.ac.uk/1420/1/0306 agiomirgianakis-et-al.pdf [Accessed: May, 2017].

Alfaro, L., Chanda, A., Kalemli-Ozcan, S. and Sayek, S. (2004) FDI and Economic Growth: The Role of Local Financial Markets, Journal of International Economics, Vol. 64, No. 1 pp. 89-112. DOI: 10.1016/S0022-1996(03)00081-3

Altomonte, C. and E. Pennings (2003) Oligopolistic Reaction to Foreign Investment in Discrete Choice Panel Data Models, IGIER Working Paper No. 243. Innocenzo Gasparini Institute for Economic Research, Milan, Italy. Available via: http://www.etsg.org/ETSG2003/papers/pennings.pdf [Accessed: May, 2017].

Amiti, M. and Wei, S. J. (2006) Service Offshoring and Productivity: Evidence from the United States. International Monetary Fund, IMF Working Paper Series: 11926. Avialable via: https://www.newyorkfed.org/medialibrary/media/research/economists/amiti/usoffshoring productivity.pdf [Accessed: May, 2017].

Ancharaz, V. D. (2003) Determinants of Trade Policy Reform in Sub-Saharan Africa, Journal of African Economies, Vol. 12, No. 3, pp. 417-443. DOI: 10.2.123

Anyanwu, J. C. (2011) Do International Remittances Affect Poverty in Africa?, African Development Review, Vol. 22, No. 1, pp. 51-91. DOI: 10.1111/j.14678268.2009.00228.x

Artige, L. and Nicolini, R. (2005) Evidence on the Determinants of Foreign Direct Investment: The Case of Three European Regions. Liège, Belgium: HEC-Management School, University of Liège. Available via: http://www.crepp.ulg.ac.be/papers/crepp-wp200607.pdf [Accessed: May, 2017].

Asiedu, E. (2002) On the Determinants of Foreign Direct Investment to Developing Countries: Is Africa Different? World Development, Vol. 30, No. 1, pp. 107-118. DOI: https://doi.org/10.1016/S0305-750X(01)00100-0 
Asiedu, E. (2003) Policy Reform and Foreign Direct Investment to Africa: Absolute Progress but Relative Decline, Development Policy Review, Vol. 22, No. 1, pp. 41-48. DOI: $10.1111 / \mathrm{j} .1467-8659.2004 .00237$.

Balasubramanyam V., Salisu N. and Sapsford M. (1996) Foreign Direct Investments as an Engine of Growth, Journal of International Trade and Economic Development, Vol. 8, No. 1, pp. 27-40. DOI: 10.1080/09638199900000003

Baum, M. A. (2000) The Political Economy of Growth: Democracy and Human Capital, American Journal of Political Science, Vol. 47, No. 2, pp. 333-347. DOI: 10.1111/15405907.00023

Blonigen, B. A., Christopher J. E. and Dietrich F. (2005) Industrial Groupings and Foreign Direct Investment, Journal of International Economics, Vol. 65, No. 1, pp. 75-91. DOI: https://doi.org/10.1016/j.jinteco.2003.12.003

Borensztein E., De Gregorio J. and Lee, J-W. (1998) How Does Foreign Direct Investment Affect Economic Growth?, Journal of International Economics, Vol. 45, No. 1, pp.115135. DOI: https://doi.org/10.1016/S0022-1996(97)00033-0

Buckley, P.J. and M. Casson (1976) The Future of the Multinational Enterprises. Macmillan: London. ISBN: 978-1-349-02901-3.

Charkrabarti, A. (2001) The Determinants of Foreign Direct Investment: Sensitivity Analyses of Cross-Country Regressions, Kyklos, Vol. 54, No. 1, pp. 89-114. DOI: 10.1111/14676435.00142

Choe, J.I. (2003) Do Foreign Direct Investment and Gross Domestic Investment Promote Economic Growth?, Review of Development Economics, No. 7, No. 1, pp. 44-57. DOI: $10.1111 / 1467-9361.00174$

Coase, R. H. (1937) The Nature of the Firm, Economica, Vol. 4, No. 16, pp. 386-405. DOI: $10.2307 / 2626876$

De Mello, L. (1999) Foreign Direct Investment Led Growth: Evidence from Time-Series and

Panel Data, Oxford Economic Papers, Vol. 5, No. 1, pp. 133-151. DOI: https://doi.org/10.1093/oep/51.1.133

Dunning, J.H. (1993) The Globalization of Business, Routledge: London, UK. ISBN: 0415096111.

Dunning, J.H. (1974) The Distinctive Nature of Multinational Enterprise, George Allen and 
Unwin: London, UK. ISBN: 0-415-31355-4.

Dunning, J.H. (1977) Trade Location of Economic Activity and the MNE: A Search of an Eclectic Approach, in B. Ohlin, P.O. Hesselborn and P.J. Wijkman (eds.), The International Allocation of Economic Activity. Macmillan: London, UK. ISBN: 978-0$333-21423-7$.

Dunning, J.H. (1979) Explaining Changing Patterns of International Production: In Defense of the Eclectic Theory, Oxford Bulletin of Economics and Statistics, Vol. 41, No. 4, pp. 269-295. DOI: 10.1111/j.1468-0084.1979.mp41004003.x

Frimpong, J.M and Oteng-Abayie, E.F. (2007) Bivariate Causality Analysis Between FDI Inflows and Economic Growth in Ghana, International Research Journal of Finance and Economics, Issue $15 . \quad$ Available via: https://mpra.ub.unimuenchen.de/351/1/MPRA_paper_351.pdf [Accessed: May, 2017].

Ganstanag V., Nugent, J. B. and Panshamova B. (1998) Host Country Reforms and FDI Inflows: How Much Difference Do They Make?, World Development, Vol. 26, No. 7, pp. 12991314. DOI: https://doi.org/10.1016/S0305-750X(98)00049-7

Goldsbrough, D. G. (1979) The Role of Foreign Direct Investment in the External Adjustment Process, Vol. 26, No. 4, pp. 725-754. DOI: 10.2307/3866968

Grossman, G. and Helpman, E. (1991) Innovation and Growth in the Global Economy, MIT Press: Cambridge, MA, USA. ISBN: 9780262071369.

Grubert, H. and Mutti, J. (1991) Taxes, Tariffs and Transfer Pricing in Multinational Corporate Decision Making, Review of Economic Studies, Vol. 73, No. 2, pp. 285-293. DOI: $10.2307 / 2109519$

Hartman, D. G. (1994) Tax Policy and Foreign Direct Investment in the United States, National Tax Journal, Vol. 37, No. 4, pp. 475-488. DOI: http://www.jstor.org/stable/41791979

Hausmann, R. and Fernandez-Arias, E. (2000) The New Wave of Capital Inflows: Sea Change or Just Another Title?, (Working Paper No. 417). Available via: https://publications.iadb.org/bitstream/handle/11319/1317/The\%20New\%20Wave\%20of\% 20Capital\%20Inflows\%3a\%20Sea\%20Change\%20or\%20Tide\%3f.pdf?sequence=1 [Accessed: May, 2017]. 
Head, K., Ries, J. and Swenson, D. (2002) Agglomeration Benefits and Location Choice: Evidence from Japanese Manufacturing Investment in the United States, Journal of International Economics, Vol. 38, No. 3/4, pp. 223-247. DOI: https://doi.org/10.1016/0022-1996(94)01351-R

Henisz, W.J. (2003) The Power of the Buckley and Casson Thesis: The Ability to Manage Institutional Idiosyncrasies, Journal of International Business Studies, Vol. 34, No. 2, pp. 173-184. DOI: 10.1057/palgrave.jibs. 8400015

Hines, J. R. and Rice, E. M. (1994) Fiscal Paradise: Foreign Tax Havens and American Business, The Quarterly Journal of Economics, Vol. 109, No.1, pp. 149-182. DOI: http://www.jstor.org/stable/2118431

Hymer, S., (1976) The International Operations of Nation Firms: A Study of Foreign Direct Investment, MLT Press: Cambridge, UK. Available via: file:///C:/Users/David/Downloads/02013925-MIT.pdf [Accessed: May, 2017].

Itaki, M. (1991), "A Critical Assessment of the Eclectic Theory of the Multinational Enterprise." Journal of International Business Studies, 25, pp. 445-460.

Jackson, S., Markowski, S. (1995) The Attractiveness of Countries to Foreign Direct Investment, Journal of World Trade, Vol. 29, No. 5, pp. 159-180. Available via: https://www.kluwerlawonline.com/abstract.php?id=TRAD1995035 [Accessed: May, 2017].

Jaspersen, F. Z., Aylward, A. H. and Knox, A. D. (2000) The Effects of Risk on Private Investment: Africa Compared with Other Developing Areas, in P. P. Collier, C. (Ed.), Investment and Risk in Africa. St Martin's Press: New York, USA. DOI: 10.1007/978-1349-15068-7_3

Jordaan, J. C. (2004) Foreign Direct Investment and Neighbouring Influences, Unpublished Doctoral Thesis, University of Pretoria. Available via: http://repository.up.ac.za/bitstream/handle/2263/24008/Complete.pdf? sequence $=4$ [Accessed: May, 2014].

Kemp, M.C. (1964) The Theory of International Trade, Prentice Hall: London. ISBN: 0137425449

Kemsley, D. (1998) The Effect of Taxes on Production Location, Journal of Accounting Research, Vol. 36, No. 2, pp. 321-341. DOI: 10.2307/2491480 
Kindleberger, C.P. (1969) American Business Abroad, Yale University Press: New Haven, CT, United States. DOI: 10.1002/tie.5060110207

Knickerbocker, F.T. (1973) Oligopolistic Reaction and Multinational Enterprise, Division of

Research, Harvard University: Cambridge, MA, United States. DOI: 10.1002/tie.5060150205

Kravis, I. B. and Lipsey, R. E. (1982) Location of Overseas Production and Production for Exports by U.S. Multinational Firms, Journal of International Economics, Vol. 12, pp. 201-223. DOI: 10.3386/w0482

Lemafalussy, A. (1961) Investment and Growth in Mature Economies, Basil Blackwell and Mott: Oxford, United Kingdom.

Lipsey, R. E. and Sjoholm, F. (2011) FDI and Growth in East Asia: Lessons for Indonesia, Bulletin of Indonesian Economic Studies, Vol. 47, pp. 35-63. DOI: 10.2139/ssrn.1689558

Loree, D. W., and Guisinger, S. (1995) Policy and Non-policy Determinants of US Equity Foreign Direct Investment, Journal of Business Studies, Vol 26, No. 2, pp. 281-299. DOI: 10.1057/palgrave.jibs.8490174

Lunn, J. (1980) Determinants of U.S. Direct Investment in the E. E. C.: Further Evidence, European Economic Review, Vol. 13, No. 1, pp. 93-101. DOI: https://doi.org/10.1016/0014-2921(80)90048-3

MacDougall, G.D.A. (1958) The Benefits and Cost of Private Foreign Investment Abroad: A Theoretical Approach, Economic Record, Vol. 36, No. 73, pp. 13-35. DOI: 10.1111/j.1475-4932.1960.tb00491.x

Mansouri B. (2005) The Interactive Impact of FDI and Trade Openness on Economic Growth: Evidence from Morocco, Paper Presented at the 12th Economic Research Forum (ERF) Conference, Cairo.

McCann P. and Mudambi, R. (2004) The Location Behavior of the Multinational Enterprise: Some Analytical Issues, Growth and Change, Vol. 35, No. 4, pp. 491-524. DOI: 10.1111/j.1468-2257.2004.00259.x

Moosa, I. A. (2005) The Determinants of Foreign Direct Investment in Mena Countries: An Extreme Bounds Analysis, The paper presented at the 12th Annual Conference of the Economic Research Forum. Available via: https://erf.org.eg/wpcontent/uploads/2016/04/PRR0421.pdf [Accessed: May, 2017]. 
Nigh, D. (1985) The Effect of Political Events on United States Direct Foreign Investment: A Pooled Time-Series Cross-Sectional Analysis, Journal of International Business Studies, Vol. 16, No. 1, pp. 3-17. DOI: 10.1057/palgrave.jibs.8490439

ODI (1997) Foreign Direct Investment Flows to Low-Income Countries: A Review of the Evidence. Available via: $\underline{\text { https://www.odi.org/sites/odi.org.uk/files/odi- }}$ assets/publications-opinion-files/2626.pdf [Accessed: May, 2017].

Olatunji, L. A. and Shahid, M. S. (2015) FDI and Economic Growth in Nigeria: A Co-integration Analysis, Business and Economic Research, Vol. 5, No. 1, pp. 243-261. Available at: file:///C:/Users/David/Downloads/6647-27479-1-PB.pdf [Accessed: May, 2017].

Olofsdotter, K. (1998) Foreign Direct Investment, Country Capabilities and Economic Growth, Review of World Economics, Vol. 134, No. 3, pp. 534-547. DOI: http://www.jstor.org/stable/40440664

Omoniyi, B. B. and Omobitan, O. A. (2011) The Impact of Foreign Direct Investment in Economic Growth in Nigeria, International Research Journal of Finance and Economics, Vol. 6, No. 73, pp.14-28. DOI:50.2887

Pärletun, J. (2008) The Determinants of Foreign Direct Investment: A Regional Analysis with Focus on Belarus. Available via: http://lup.lub.lu.se/luur/download?func=downloadFile\&recordOId=1336912\&fileOId=164 6641 [Accessed: May, 2017].

Porcano, T. M. and Price, C. E. (1996) The Effects of Government Tax and Non-Tax Incentives on Foreign Direct Investment, Multinational Business Review, Vol. 4, pp. 9-20. Available via: $\quad$ https://www.questia.com/read/1P3-9302201/the-effects-of-government-tax-andnontax-incentives [Accessed: May, 2017].

Romer, P.M. (1990) What Determines the Rate of Growth and Technological Change?, World Banking Working Paper No. 279. Available via: http://documents.worldbank.org/curated/en/539181468739268477/pdf/multiOpage.pdf [Accessed: May, 2017].

Saunders, R. S. (1982) The Determinants of Foreign Direct Investment, Canadian Journal of Economics, Vol. 15, No.10, pp. 77-84. DOI: 2.59270. 
Schneider, F., Frey, B. (1985) Economic and Political Determinants of Foreign Direct Investment, World Development, Vol. 13, No. 2, pp. 161-175. DOI: https://doi.org/10.1016/0305-750X(85)90002-6

Seabra, F and L. Flach (2005) Foreign Direct Investment and Profit Outflows: A Causality Analysis For the Brazilian Economy, Economics Bulletin, Vol. 6, No. 1, pp.1-15. Available via: http://www.accessecon.com/pubs/EB/2005/Volume6/EB-04F30012A.pdf [Accessed: May, 2017].

Shatz, H. J. and Venables, A. J. (2000) The Geography of International Investment, Policy Research Working Paper 2338, The World Bank. DOI: http://dx.doi.org/10.1596/18139450-2338

Sethi D, Guisinger S.E., Phelan S.E and Berg D.M (2003) Trend in Foreign Direct Investment F lows: A Theoretical and Empirical Analysis, Journal of International Business Studies Vol. 34, No. 4, pp. 315-326. DOI: http://www.jstor.org/stable/3557177

Takii, S. (2005) Productivity Spillovers and Characteristics of Foreign Multinational Plants in Indonesian Manufacturing 1990-1995, Journal of Development Economics, Vol. 76, No. 2, pp. 521-542. DOI: https://doi.org/10.1016/j.jdeveco.2004.01.006

Takii, S. (2011) Do FDI Spillovers Vary Among Home Economies? Evidence from Indonesian Manufacturing, Journal of Asian Economics, Vol. 22, pp.152-163. DOI: https://doi.org/10.1016/j.asieco.2010.12.002

Tsai, P. (1994) Determinants of Foreign Direct Investment and its Impact on Economic Growth, Journal of Economic Development, Vol. 19, No. 1, pp. 137-163. DOI: 5.2334

Tsikata, G.K., Asante, Y., and Gyasi, E.M. (2000) Determinants of Foreign Direct Investment in Ghana, Overseas Development Institute. Available via: https://www.odi.org/sites/odi.org.uk/files/odi-assets/publications-opinion-files/8125.pdf [Accessed: May, 2017].

UNCTAD (1998). World Investment Report. UNCTAD, Geneva. Available via: http://unctad.org/en/Docs/wir1998_en.pdf [Accessed: May, 2017].

UNCTAD (2002) World Investment Report (Various issues), Geneva, UN. Available via: http://unctad.org/en/Docs/wir2002overview_en.pdf [Accessed: May, 2017].

Wheeler, D., Mody, A. (1992) International Investment Location Decisions: The Case for U.S. 
Firms, Journal of International Economics, Vol. 33, No. 1-2, pp. 57-76. DOI: https://doi.org/10.1016/0022-1996(92)90050-T

World Bank (2012) World Bank Indicators, Online Database, World Bank. Available via: worldbank.org/curated/en/.../pdf/113647-REVISED-PUBLIC.pd [Accessed: May, 2017].

World Investment Report (WIR) (2012) Non-equity Modes of International Production and Development. New York and Geneva: United Nations. Available via: http://unctad.org/en/publicationslibrary/wir2011_en.pdf [Accessed: May, 2017]. 
Table 1 - Descriptive Summary

\begin{tabular}{lllllll}
\hline Variables & N & Mean & Median & SD & Skewness & Kurtosis \\
\hline Ln FDI & 39 & 18.386 & 18.483 & 2.3017 & 0.1801 & 1.933337 \\
Ln Electricity & 43 & 5.7303 & 5.8112 & 0.2891 & -2.077 & 8.423234 \\
Ln GDP & 42 & 1.5219 & 1.5789 & 0.6523 & -2.214 & 9.682846 \\
Ln inflation & 49 & 3.0547 & 2.8975 & 0.7820 & 0.3417 & 3.010716 \\
Ln REEXR & 36 & 5.1396 & 4.8097 & 0.9642 & 1.8996 & 5.713947 \\
Ln Openness & 50 & 3.8409 & 3.8053 & 0.6583 & -0.905 & 3.584958 \\
\hline
\end{tabular}


Table 2 - Unit Root Tests Results

\begin{tabular}{llll}
\hline Variables & Test for Unit root & ADF Statistic & Decision \\
\hline Growth & Constant & $-7.231^{* * *}$ & Stationary \\
& Constant with trend & $-5.929 * * *$ & Stationary \\
FDI & Constant & -0.545 & Not Stationary \\
Electricity & Constant with trend & $-3.490^{* *}$ & Stationary \\
& Constant & $-2.630^{*}$ & Stationary \\
Open & Constant with trend & $-3.654^{* *}$ & Stationary \\
\multirow{2}{*}{ Inflation } & Constant & $-2.946 * * *$ & Stationary \\
& Constant with trend & $-6.828^{* * *}$ & Stationary \\
Real Exchange Rate & Constant & $-2.608^{*}$ & Stationary \\
& Constant with trend & $-3.628 * * *$ & Stationary \\
& Constant & -2.547 & Not Stationary \\
\hline
\end{tabular}

$*, * *, * * *$ denotes significant at $1 \%, 5 \%$ and $10 \%$ 
Figure 1 - Time Series Plot of Variables
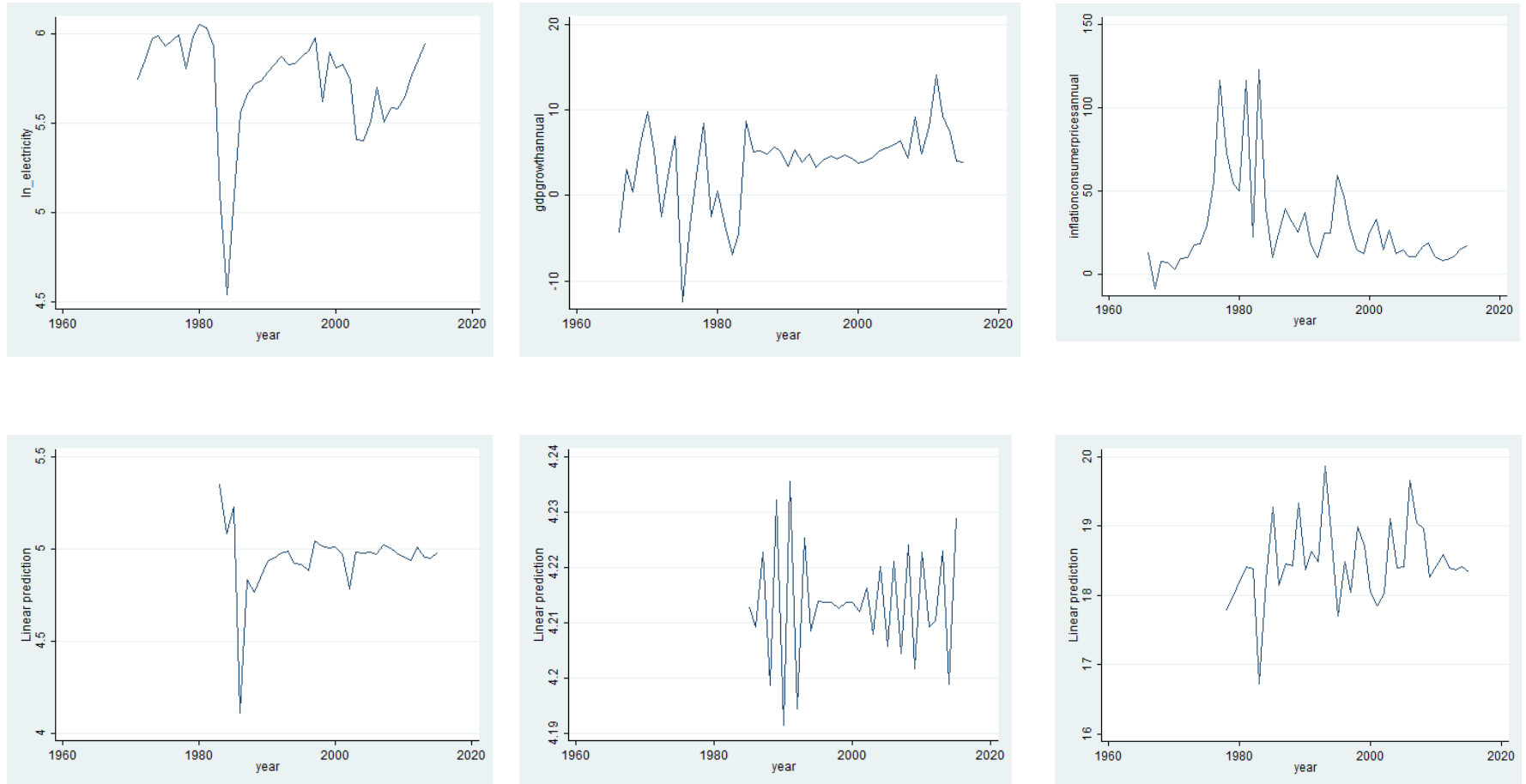
Table 3 - Johansen's Cointegration Rank Test

\begin{tabular}{lllll}
\hline Maximum rank & LL & Eigenvalue & $\begin{array}{l}\text { Trace } \\
\text { statistic }\end{array}$ & $\mathbf{5 \%}$ critical value \\
\hline 0 & 36.084425 & & 116.9669 & 94.15 \\
1 & 57.206585 & 0.77881 & 74.7225 & 68.52 \\
2 & 73.302725 & 0.68328 & $42.5303^{*}$ & 47.21 \\
3 & 83.23091 & 0.50794 & 22.6739 & 29.68 \\
4 & 89.107063 & 0.34277 & 10.9216 & 15.41 \\
5 & 93.628073 & 0.27597 & 1.8796 & 3.76 \\
6 & 94.567856 & 0.06492 & & \\
\hline
\end{tabular}


Table 4 - Johansen VECM models for Cointegration Tests

\begin{tabular}{lll}
\hline Dependent Variable & Chi Square & Conclusion \\
\hline LnFDI | (lnElectricity, lnGDP, ln_Infl, ln_REEXR, lnOpen) & $16.8417^{* *}$ & Cointegration \\
lnElectricity | (LnFDI, lnGDP, ln_Infl, ln_REEXR, lnOpen) & $16.68719^{* *}$ & Cointegration \\
lnGDP | (lnElectricity, LnFDI, ln_Infl, ln_REEXR, lnOpen) & $37.37948^{* * *}$ & Cointegration \\
ln_Infl | (lnElectricity, lnGDP, LnFDI , ln_REEXR, lnOpen) & 14.17697 & No Cointegration \\
ln_REEXR | (lnElectricity, lnGDP, ln_Infl, LnFDI, lnOpen) & $62.93604^{* * *}$ & Cointegration \\
lnOpen | (lnElectricity, lnGDP, ln_Infl, ln_REEXR, LnFDI) & 13.56206 & No Cointegration \\
\hline
\end{tabular}


Table 5 - Determinants of FDI inflows

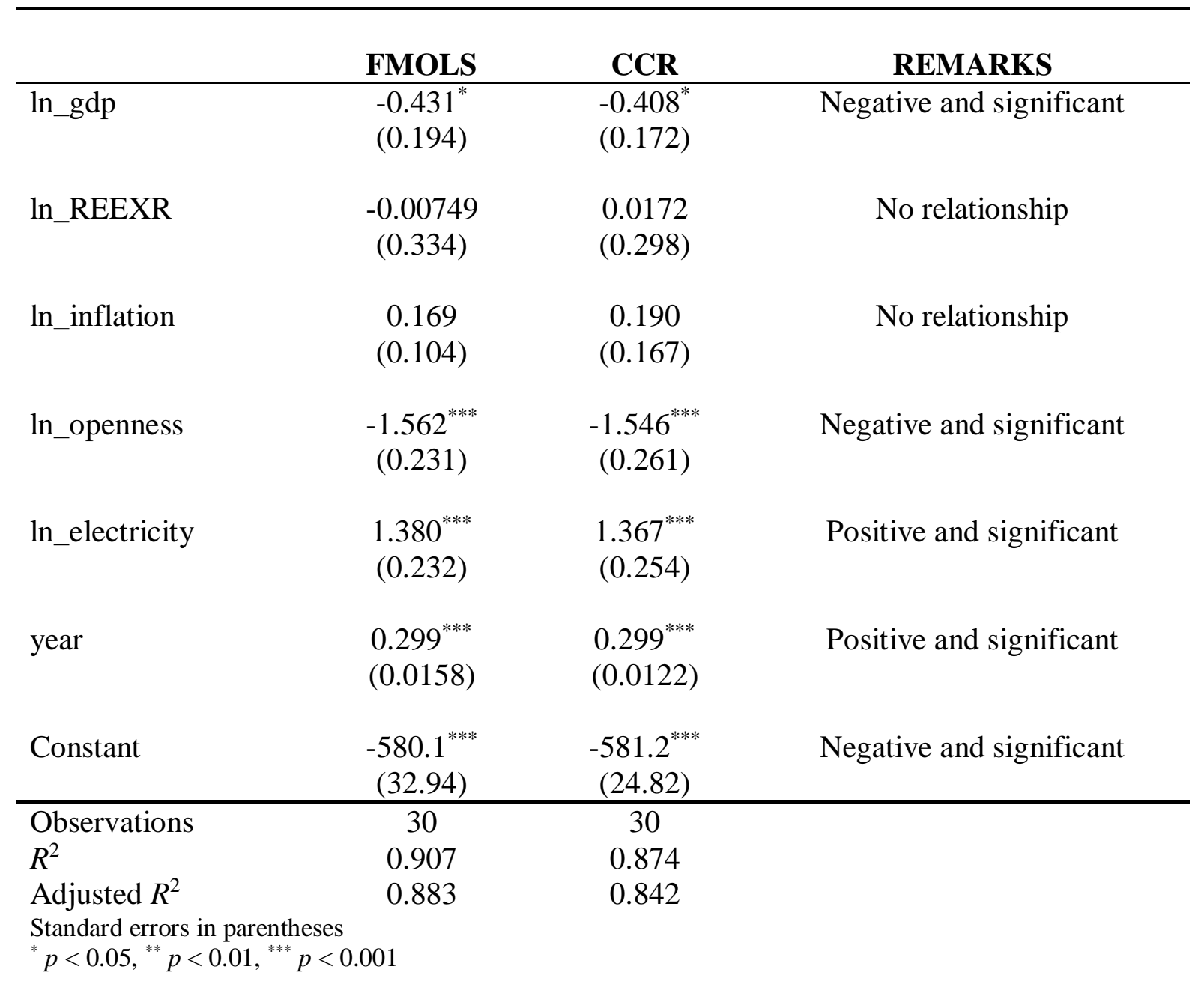


Table 6 - Granger causality Wald tests

\begin{tabular}{lllll}
\hline & Excluded & Chi-square & df & Prob>chi2 \\
\hline Ln_FDI & Ln_Electricity & .30591 & 1 & .580 \\
Ln_FDI & All & .30591 & 1 & .580 \\
& & & & \\
Ln_Electricity & Ln_FDI & 8.7423 & 1 & .003 \\
Ln_Electricity & All & 8.7423 & 1 & .003 \\
\hline
\end{tabular}


Table 7 - VAR Analysis

$\begin{aligned} & \text { |lag | } \text { LL } \\ & \mid\end{aligned}$


Table 8 - VAR Stability and Autocorrelation Tests

\begin{tabular}{llllll}
\hline $\begin{array}{l}\text { Eigenvalue stability condition } \\
\text { Eigenvalue }\end{array}$ & Modulus & \multicolumn{4}{l}{ Lagrange-multiplier test } \\
\hline .7683365 & Lag & Chi2 & df & Prob> chi2 \\
.768336 & 1 & 3.0804 & 4 & 0.54446 \\
.2481047 & .248105 & 2 & 1.0728 & 4 & 0.89856 \\
\hline
\end{tabular}


Figure 2 - Forecasts of FDI and Electricity Consumption

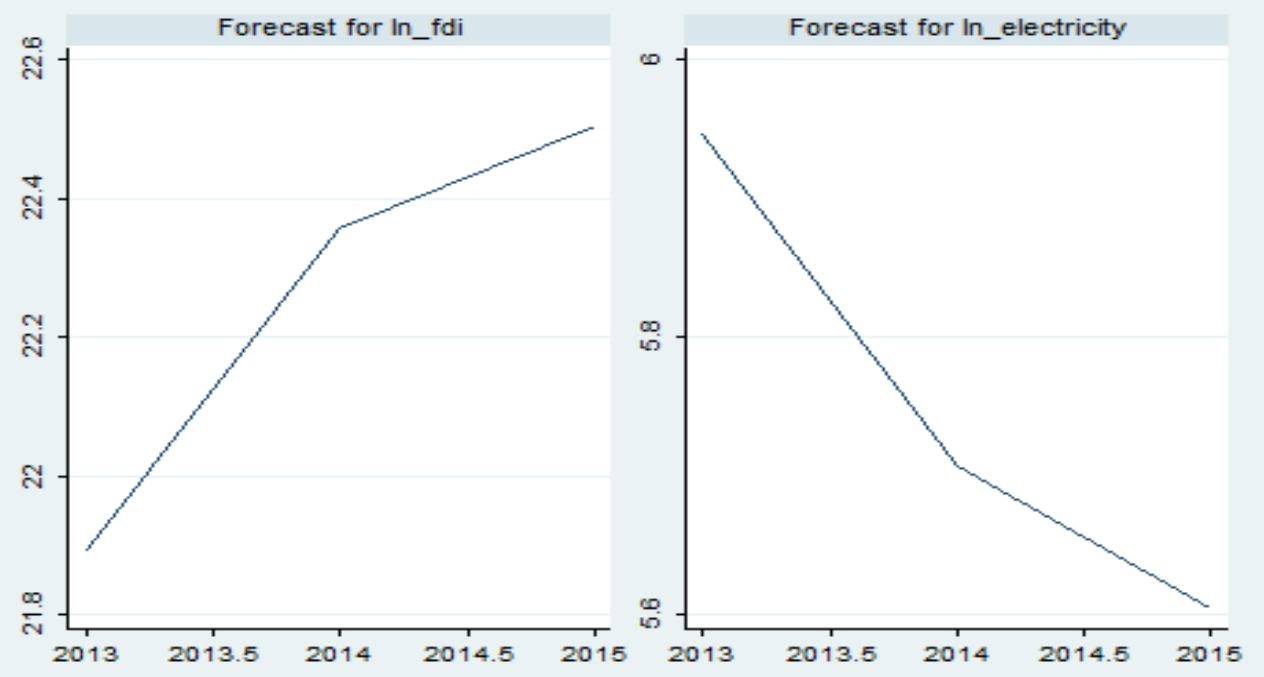


Figure 3 - Impulse Response
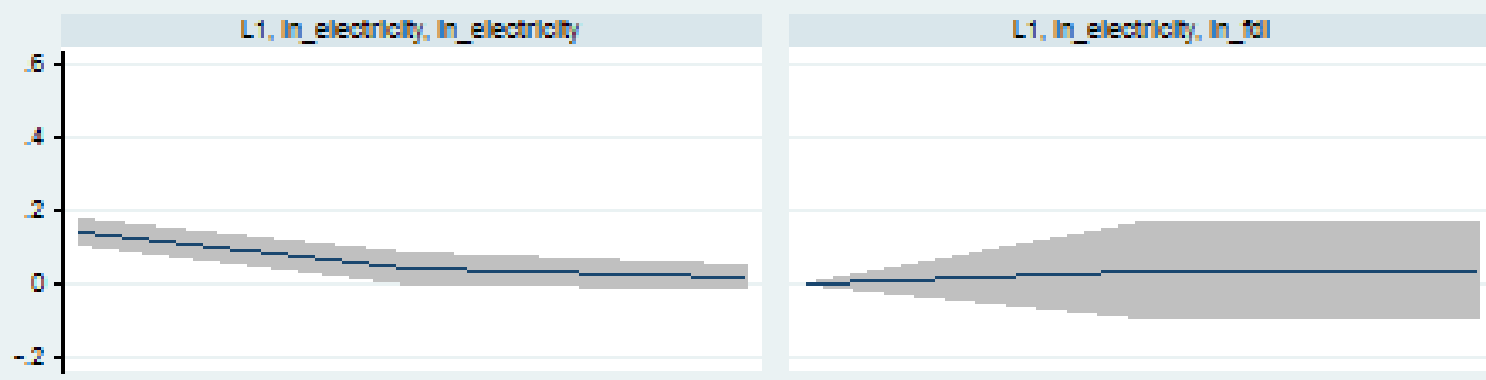

L1, In_fol, in_electricing

L1, In_tol, In_tol

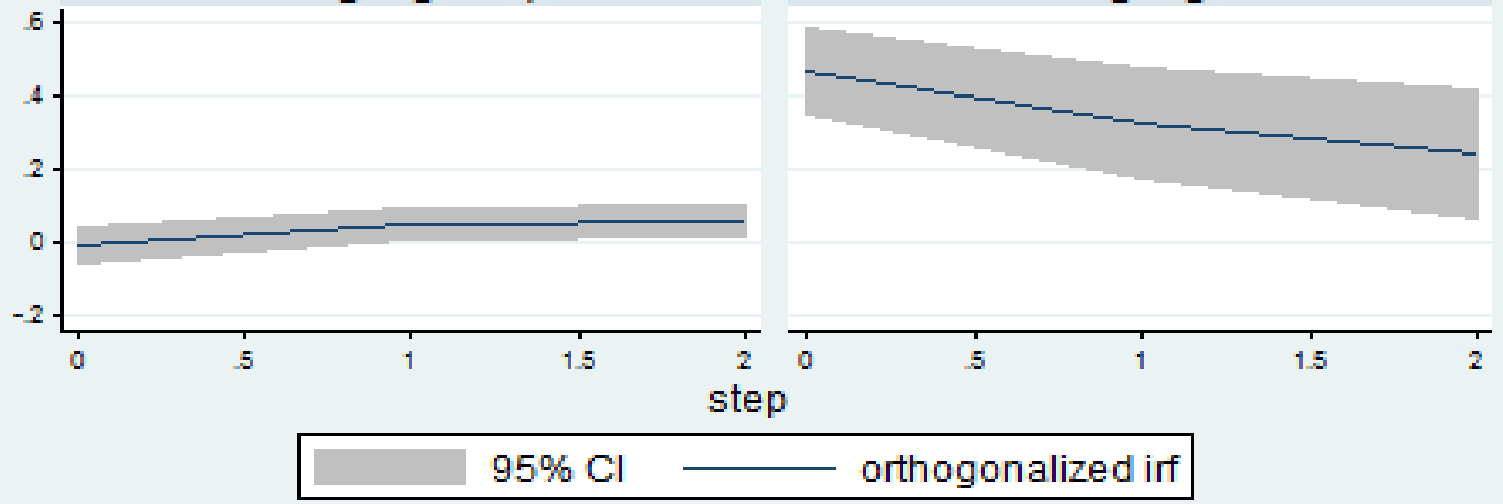

Graphs by irfname, impulse variable, and response variable

NB: Impulse response assuming that the VAR residuals are uncorrelated 
Figure 4 - Plots Forecast Error Variance Decomposition

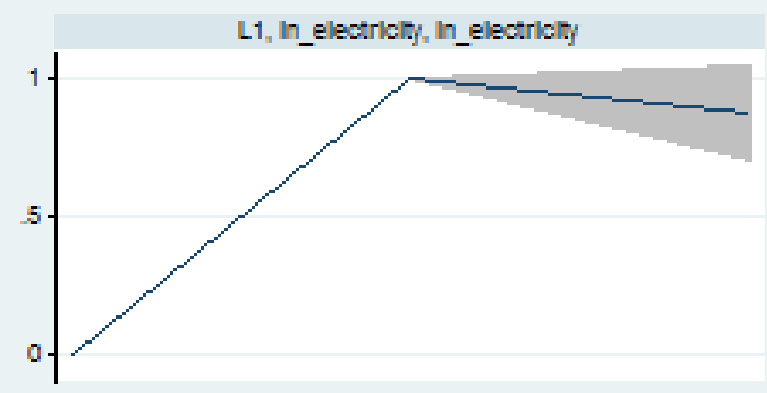

L1, In_electriciny, in_tol

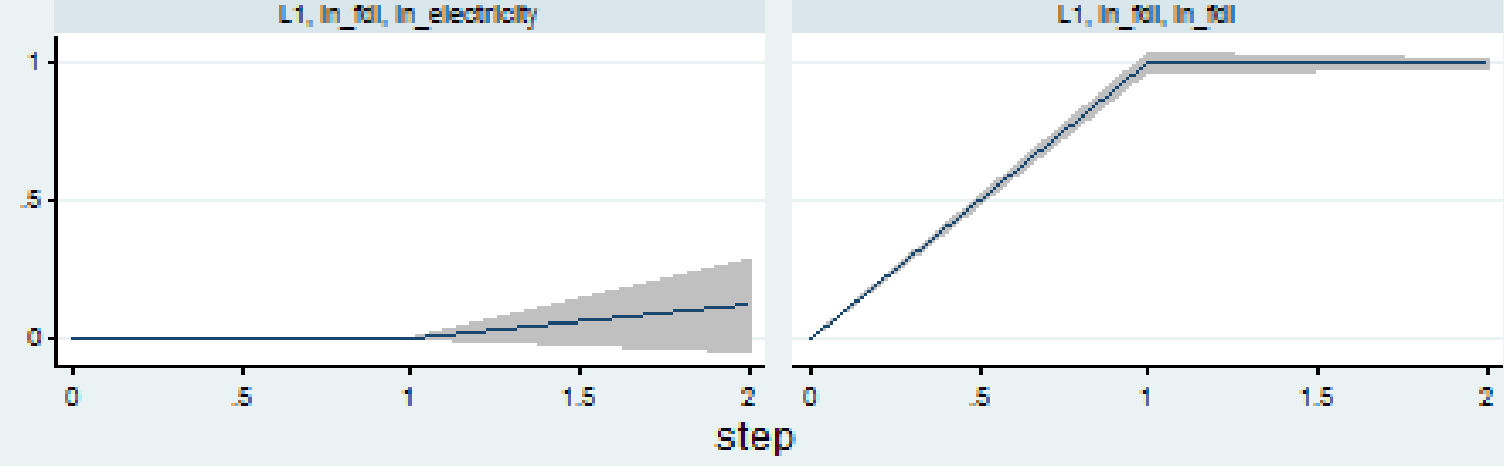

$95 \% \mathrm{Cl}$ - fraction of mse due to impulse

Graphs by irfname, impulse variable, and response variable 